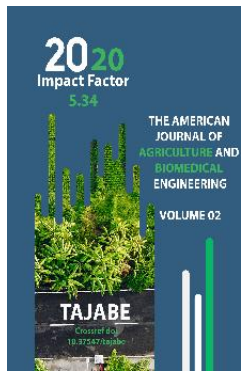

\title{
Endemic Species Of Flora Kuhitang Ridge
}

\author{
Ibragimov Akram Javliyevich \\ Teacher, Termiz State University, Uzbekistan \\ Karimov Baxtiyor Qurbon O'g'li \\ Teacher, Termiz State University, Uzbekistan
}

Copyright: Original

content from this work

may be used under the

terms of the creative

commons attributes

4.0 licence.

\section{ABSTRACT}

The article says that of the 25 endemic species of the Kugitang flora, 18 species are found in the eastern part of the ridge, i.e. within Uzbekistan. All endemic to the Uzbek part are protected by the Surkhan reserve. This indicator indicates the great importance of the Surkhan reserve in the gene pool of the Kugitang plant diversity.

\section{KEYWORDS}

Endemic, reserve, plants, perennials, rhizome plants.

\section{INTRODUCTION}

An assessment of the floristic wealth of the Kugitang ridge was first given by S.A. Nevsky [1], who identified 675 species in the flora. 588 species he cited for his collections. At one time, this work was the standard of floristic analysis of mountain territories. But the work did not address the topic of endemic Kugitang plants. A detailed analysis of the flora of the Kugitang ridge was done by R.V. Kamelin [2].
According to the results of his calculations, at least 860 species are found only in Western Kugitang, while the total number of Kugitang flora species is estimated to be at least 1000 species. R.V. Kamelin highly appreciates the endemism of the flora, indicating a relict and at the same time young progressive character. Among the endemic species are species from various groups - Astragalus bobrovii B. 
Fedtsch. (monotypic section Astenolobium Gontsch.), A. plumbeus (Nevski) Popov, A. willisii Popov, Euphorbia spinidens Bornm., Zygophyllum bucharicum B. Fedtsch., Hymenocrater incisodentalus Boriss., Otostegia bucharica B. Fedtsch., Cii. C.leptoclada Kult. and etc.

According to F.U. Khasanova [3] only in the tree-shrubby vegetation of the Kugitang ridge there are 578 species belonging to 269 genera and 55 families. The work indicates 13 endemic species - Astragalus plumbeus (Nevski) Gontsch, A. rubri-galli Popov, A.willisi Popov, Oxytropis pseudoleptophysa Boriss, Seseli nevskii (Korov.) M. Pimen. et Sdobn., Acantholimon majevianum Regel, Lappula nevskii Raenko, Phlomis thapsoides Bunge, Neogaillonia botschantzevii Lincz., Cousinia spryginii Kult., C. dimoana Popov, Echinops multicaulis Nevski, Jurinea popovii Iljin. Khasanova [3] only in the tree-shrubby vegetation of the Kugitang ridge there are 578 species belonging to 269 genera and 55 families. The work indicates 13 endemic species - Astragalus plumbeus (Nevski) Gontsch, A. rubri-galli Popov, A.willisi Popov, Oxytropis pseudoleptophysa Boriss, Seseli nevskii (Korov.) M. Pimen. et Sdobn., Acantholimon majevianum Regel, Lappula nevskii Raenko, Phlomis thapsoides Bunge, Neogaillonia botschantzevii Lincz., Cousinia spryginii Kult., C. dimoana Popov, Echinops multicaulis Nevski, Jurinea popovii Iljin.

In recent years, we have been studying the flora of the Surkhan reserve, located on the Uzbek part of the ridge. As a result of field studies and analysis of literature data $[3,4,5$, $8,9,10], 25$ species of endemic plants are given for the entire Kugitang ridge. Most endemics are representatives of the leading families of the Central Asian flora. The following is a list of Kugitang endemic.

MATERIALS AND METHODS
Acantholimon majevianum Regel (Limonaceae) is a common species of Kugitang flora. It grows on the territory of the Surkhan Reserve, where it is found in the northern part of Bagli-Dara and Tangi-Duval. It grows on gravel and rocky slopes and peaks of watersheds at an altitude of 1000-2100 m above sea level. It plays a significant role in the vegetation cover, is part of many phytocenoses of the upper foothills and mountains, (the abundance of sp1-sp2) in some places dominates the associations of upland xerophytes.

Allium kugitangii F.Khassanov (Alliaceae) is a rare species for the flora of the Surkhan reserve, we have recorded several small populations on the fine-grained, rocky-finegrained slopes of Bagli-Dara. The abundance does not exceed 10-12 plants per $100 \mathrm{m2}$ [6].

Astragalus aemulans (Nevski) Gontsch. (Fabaceae) - It is rare. It grows in western Kugitang, in the areas of Khojafilat and Markushi. It lives on rocky and gravelly slopes at an altitude of 1800-2200 m. at. m. A. kahiricus DC. - according to Nikitin and Geldikhanov [5] found in the southwestern Kugitang, between Kelif and Okuzbulak. Grows on the sandy hilly slopes of the foothills, at an altitude of $600-800 \mathrm{~m}$ above sea level. A. plumbeus (Nevski) Gontsch. et Popov. - is extremely rare, grows in the northern part of the Khuzhanka site, Surkhan reserve. It lives on limestone and gravelly slopes, at an altitude of $1100-1500 \mathrm{~m}$. at. m., the abundance of sp1. A. rubri-galli Popov rarely found, narrow endemic of the western Kugitang, noted near Kelif. It lives at the outputs of variegated rocks at an altitude of $850-1000$

m above sea level. A. subschachimardanus Popov- populations are protected in the northern part of the Kizyl-alma section of the Surkhan reserve. It lives on stony, stony- 
gravelly slopes, and gentle peaks of water sections at an altitude of $1800-2800 \mathrm{~m}$ above sea level, an abundance of sp2-sp3.

Cousinia bobrovii Juz. (Asteraceae) - it is found occasionally, grows on the Turkmen part of the Kugitang ridge. It lives on fine-grained, stony-fine-grained slopes at an altitude of 1000-1800 m above sea level. C. glabriseta Kult. - an extremely rare species, we noted only one habitat on the northern slope of the site of Kizyl alma, Surkhan reserve. Grows on fine-grained and fine-grained-gravelly soils in the middle zone of mountains, at an altitude of $15001800 \mathrm{~m}$ above sea level The abundance does not exceed 10-12 plants per $100 \mathrm{m2}$. C. leptoclada Kult. - is rare. It grows only in the eastern part of the Surkhan reserve, in the northern part of the Kizyl alma site. It lives on rocky and gravelly slopes at an altitude of 1800-2500 m above sea level, an abundance of sol - sp1. C. triceps Kult. - Occurs occasionally. Marked only on the site of Kizyl alma, Surkhan reserve. It grows in solitary individuals, on stony and gravelly slopes and watersheds up to $2700 \mathrm{~m}$ above sea level, an abundance of sp1.

Ferula nevskii Korov. ex Nevski (Apiaceae) is a common species of Kugitang flora, found almost throughout its territory on finegrained, stony, stony-gravelly slopes at an altitude of 1500-2000 m above sea level, the abundance of sol is sp1. Haplophyllum vvedenskyi Nevski (Rutaceae) - is rare. Grows in the southern part of the Bagli-Dara (Surkhan Reserve) and the western part, in the vicinity of the village of Kugitang. The populations are distributed on fine-grained, stony-finegrained slopes. The altitude interval is narrow, all the noted populations are spread over $1100-1400 \mathrm{~m}$ above sea level, the abundance of sp1.
Jurinea tapetodes Iljin (Asteraceae) - is rare. In eastern Kugitang, it was recorded in several sections of the Surkhan reserve - Kampirtep, Sherjan and Vandop. Distributed on gravel and rocky slopes, on rocks from 2200 to $2800 \mathrm{~m}$ above sea level, an abundance of sp1.

Lepidolopha fedtschenkoana Knorr. (Asteraceae) is a rare species for the flora of the Surkhan Nature Reserve, we have recorded several small populations on rocky cliffs, rocky and gravelly slopes of Bagli-Dara and Tangi-Duval. The lower boundary of the distribution of populations passes at an altitude of $1000 \mathrm{~m}$ above sea level. It occurs singly, an abundance of sol.

Neogaillonia trichophylla (Popov ex Tschern.) Lincz. (Rubiaceae) - It is rare. It lives on the dry gravel and gravel-clay slopes of the southern part of the Surkhan reserve, in the area of the Vandop site. The interval is from 800 to 1200 $\mathrm{m}$ above sea level, an abundance of sol.

Onobrychus nikitinii Orazmuchommedov (Fabaceae) - is very rare. In eastern Kugitang, it grows in the territory of the Surkhan reserve (Bagli-Dara). It is possible to be in the Turkmen part of the ridge, in the vicinity of Khojafilat. Throughout the reserve, all noted local populations grow on stony-fine-grained slopes of the upper mountain belt, at an altitude of 2100-2400 $\mathrm{m}$ above sea level. The abundance reaches 10-15 individuals per 100 $\mathrm{m} 2$.

Oxytropis megalorrhyncha Nevski (Fabaceae) is rare. Distributed in separate areas of both Kugitang macroscopes. In the Uzbek part, we recorded in the northern part of the Kizyl alma site (the territory of the reserve) and several localities are given in the literature [5] for Khojafilat. It lives on rocky and gravelly slopes 
at an altitude of $1800-2300 \mathrm{~m}$ above sea level, the abundance does not exceed the level of sol. O. pseudoleptophysa Boriss. - a rare species of flora of the Surkhan reserve. Only two small populations are known. We noted the first on the stony slope of the upper part of Kampirtep (2500-2700 m above sea level) and the second on the stony and gravelly slope of the northern part of Kizyl alma (2100$2600 \mathrm{~m}$ above sea level).

Scutellaria nevskii Juz. Et Vved. (Lamiaceae) grows on western Kugitang. It occurs on finegrained and stony-gravelly slopes at an altitude of 2000-2500 m above sea level. [5]. S. heterotricha Juz. Et Vved. - is given for the northern part of the Khuzhanka site, possibly in the vicinity of Sayat. It lives on rocky outcrops and along gorges at an altitude of 1500-2000 m above sea level, an abundance of sol-sp1.

Seseli nevski (Korovin) M. Pimenov et Sdobnnina (Apiaceae) - all over Kugitang met B.M. evenly, especially in the eastern part. Small populations are given for Khojafilat, Naich, the village of Kugitang, the Turkmen part of the ridge and the upper part of Kampirtepe, Surkhan reserve. Grows on stony, stony-gravelly slopes at an altitude of 1500$2100 \mathrm{~m}$. at. m., the abundance of sol-sp1.

Taraxacum gnezdilloi Kovalevsk. (Asteraceae) - is found in the southern part of the sites of Sherjan and Kampirtepe, Surkhan reserve. Individuals are confined to fine-grained and stony slopes (1200-1800 m above sea level), the abundance of sp1.

In addition to the "faithful" endemic, 5 subendemic species grow in the Kugitang ridge: Astragalus bobrovii - given for the Gissar ridge: to the south and east of the Yakkabag settlement, a lesson. Khan-ottoman A. willisii Popov - southern part of the KattaKurchuk mountain; Salvia lilacinocoerulea Nevski and Euphorbia densiuscula Popov. Phlomis spinidens Nevski - reaches the southern part of the Baysun-tau ridge. Of the 25 endemic species of the Kugitang flora, 18 species are found in the eastern part of the ridge, i.e. within Uzbekistan. All endemic to the Uzbek part are protected by the Surkhan reserve.

\section{CONCLUSION}

This indicator indicates the enormous importance of the Surkhan Reserve in preserving the gene pool of the Kugitang plant diversity. Five species from the Kugitang endemic (Astragalus plumbeus (Nevski) Gontsch. Et Popov, A. subschachimardanus Popov, Cousinia glabriseta Kult., Lepidolopha fedtschenkoana Knorr., Oxytropis pseudoleptophysa Boriss.) are listed in the Red Book of Uzbekistan [7]. For all these species, the reasons for the change in the number and range have not been established, and protection measures have not been developed, which indicates the need to study the state of natural populations and the bioecological characteristics of the endemic Kugitang species.

\section{REFERENCES}

1. Nevsky S.A. Materials for the flora of Kugitang and its foothills.-Sat: Flora and systematics of higher plants. -M.-L. USSR Academy of Sciences 1937.p. 199-346.

2. Kamelin R.V Phlorogenetic analysis of the natural flora of the mountainous Central Asia. L. Science 1973. p 95-96.

3. Khasanov F. U. Xerophilic tree-shrubby vegetation Kugitang-tau. Abstract. Thesis for the scholarship. step. Cand. Biol. sciences. Tashkent 1987.p. 20.

4. Key to plants of Central Asia. T: 1-10. Tashkent, Fan, 1968-1993. 
5. Nikitin V.V., Geldikhanov A.M. Key to plants of Turkmenistan. L. Science 1988. From 678.

6. Ibragimov A.J. Flora of Surkhan State Nature Reserve (Kugitang Range): Author, dis ... cand. biol. sciences. - Tashkent, 2010. $22 \mathrm{p}$.

7. The Red Book of the Republic of Uzbekistan. Tashkent: Chinor ENK, 2009.V. 1. - p. 335 .

8. Flora of the USSR. In the 30th vol. M., L.: Ed. USSR Academy of Sciences, 1934-1964.

9. Flora of Turkmenistan. In the 7th vol. Ashgabat: Publ. AN Turkmen. SSR, 19321960.

10. Flora of Uzbekistan. In the 6th vol. Tashkent: Ed. Academy of Sciences of the Uzbek SSR, 1941-1962. 